\title{
Pengaruh Ekstrak Kulit Buah Kakao (Theobroma cacao) Dalam Menghambat Penyakit Layu Fusarium Terhadap Pertumbuhan Tanaman Tomat
}

\section{Effect of Cocoa (Theobroma cacao) Skin Extract in Inhibiting Fusarium Withered Disease on Tomato Plant Growth}

\author{
Abdillah ${ }^{1}$, Rachmawaty ${ }^{1}$, A. Mu' nisa ${ }^{1}$ \\ 1Prodi Biologi, Fakultas Matematika dan Ilmu Pengetahuan Alam, Universitas Negeri \\ Makassar
}

Received $8^{\text {th }}$ February $2019 /$ Accepted $28^{\text {th }}$ March 2019

\begin{abstract}
ABSTRAK
Tanaman budidaya tidak dapat dipisahkan dari penyakit, penyakit ini disebabkan oleh patogen yang dapat merusak proses fisiologi tanaman. patogen ini dapat berupa bakteri atau jamur. Layu fusarium disebabkan oleh fusarium oxysporum, pada tomat penyakit ini disebabkan oleh fusarium oxysporum f. sp lycopersici. Penyakit ini bisa menyebabkan kerugian besar bagi petani. Penggunaan fungisida sintetik telah banyak digunakan untuk mengendalikan penyakit yang disebabkan oleh fusarium oxysporum tetapi memiliki efek buruk yang besar terhadap lingkungan, oleh karena itu diperlukan fungisida biologis yang ramah lingkungan dalam mengendalikan penyakit. Penelitian ini bertujuan untuk menguji efektivitas fungisida alami yang diperoleh dari buah kakao. Dalam penelitian ini 6 perlakuan digunakan, P0 (kontrol tanaman sehat tanpa pengobatan), P1 (kontrol tanaman sakit diobati F. oxysporum), P2 (pengobatan ekstrak kakao 2\% + perlakuan F. oxysporum) P3 (pengobatan ekstrak buah kakao ekstrak 5\% + perlakuan F. oxysporum), P4 (perlakuan ekstrak buah kakao 8\% + perlakuan F. oxysporum) P5 (perlakuan benomyl + perlakuan F. oxysporum) Hasil penelitian menunjukkan bahwa fungisida nabati dari ekstrak biji kakao mampu menghambat layu fusarium. Setiap perlakuan memiliki efek yang sama pada tinggi maksimum tanaman tomat, jumlah buah dan berat buah. Tinggi tanaman tertinggi, jumlah daun dan berat buah tertinggi pada perlakuan ekstrak $8 \%$ dan terendah adalah $2 \%$ perlakuan ekstrak.
\end{abstract}

Kata Kunci : Layu Fusarium, Fusarium Oxysporum, Fungisida Alami

\section{ABSTRACT}

Cultivation plants are inseparable from disease, this disease is caused by pathogens that can damage plant physiology processes. these pathogens can be either bacteria or fungi. Fusarium wilt is caused by fusarium oxysporum, in tomatoes this

* Korespondensi:

email: abdillah.noor01@gmail.com 
disease is caused by fusarium oxysporum $f$. sp lycopersici. This disease can cause huge losses to farmers. The use of synthetic fungicides has been widely used to control diseases caused by fusarium oxysporum but has a major adverse effect on the environment, therefore it is necessary to have an environmentally friendly biological fungicide in controlling the disease. This study aims to examine the effectiveness of natural fungicides obtained from cocoa pods. In this study 6 treatments were used, PO (control of healthy plants without treatment), $P 1$ (control of sick plants treated $F$. oxysporum), P2 (treatment of $2 \%$ cocoa pods extract + treatment of $F$. oxysporum ) P3 (treatment of cocoa pods extract $5 \%+$ treatment of F. oxysporum ), P4 (treatment of 8\% cocoa pods extract + treatment of F. oxysporum) P5 (treatment of benomyl + treatment F. oxysporum ) The results showed that vegetable fungicides from cocoa pods extract were able to inhibit fusarium wilt. Each treatment has the same effect on the maximum height of tomato plants, number of fruits and weight of fruit. The highest plant height, number of leaves and highest fruit weight was at $8 \%$ extract treatment and the lowest was $2 \%$ extract treatmen.

Keywords: fusarium wilt. Fusarium oxysporum, natural fungicide

\section{PENDAHULUAN}

Kakao (Theobroma cacao L.) merupakan salah satu komoditi ekspor Negara Indonesia dengan nilai jual yang cukup tinggi. Pada saat panen, umumnya petani memanen biji kakao untuk diolah menjadi cokelat, dan menghasilkan limbah yang banyak. Keberadaan limbah tersebut sering kali tidak dimanfaatkan secara baik dan kadang dibiarkan begitu saja menjadi sampah pertanian. Limbah kulit buah kakao yang dihasilkan dalam jumlah banyak akan menjadi masalah jika tidak ditangani dengan baik karena produksi limbah padat ini mencapai lebih dari $60 \%$ dari total produksi buah (Harsini dan Susolowati, 2007).

Buah kakao terdiri dari kulit buah, pulp, keping biji dan plasenta. Kulit buah kakao merupakan bagian terbesar dari buah kakao. Buah kakao terdiri dari $75 \%$ kulit buah, 3\% plasenta, 22\% biji. Dengan demikian semakin meningkatnya produksi biji kakao, mengakibatkan semakin meningkatnya kulit buah kakao yang terbuang. Kulit buah kakao mempunyai komposisi kimia yang cukup kompleks. Salah satu bahan kimia yang dikandungnya adalah fenol. Fenol merupakan senyawa kimia yang bersifat antimikroba. Senyawa antimikroba adalah senyawa biologis atau kimia yang cukup kompleks. Salah satu bahan kimia yang dikandungnya adalah fenol. Fenol merupakan senyawa kimia yang bersifat antimikroba. Senyawa antimikroba adalah senyawa biologis atau kimia yang dapat menghambat pertumbuhan dan aktifitas mikroba. Berdasarkan hal tersebut, kulit buah kakao memiliki potensi untuk dapat dijadikan sebagai salah satu alternatif pengendali dalam menghambat pertumbuhan mikroba patogen yang menyebabkan penyakit tanaman

Senyawa yang terkandung dalam kulit buah kakao mampu menghambat jamur $F$. oxysporum yang diujikan secara in vitro (Rachmawaty et al., 2018). Jamur $F$. oxysporum merupakan penyebab layu dan busuk batang pada berbagai jenis tanaman pangan, hortikultura dan perkebunan. Salah satu inang dari pathogen ini adalah tanaman tomat (Solanum lycopersicum) (Semangun, 2004). Infeksi jamur fusarium pada tanaman tomat menyebabkan penyakit yang dikenal dengan istilah layu fusarium. Kerusakan akibat serangan cendawan pathogen dapat mencapai $100 \%$ (Safitri dan Aris, 2007). 
Pengendalian penyakit layu fusarium selama ini menggunakan fungisida sintetis. Berbagai produk fungisida sintetis telah digunkan untuk menghambat layu fusarium, salah satu produk yang sering digunkan adalah benlox $50 \mathrm{wp}$ yang mengandung bahan aktif berupa benomyl. Selama ini benlox digunakan untuk mengatasi penyakit layu fusarium dan penyakit rebah semai pada tanaman cabai dan tomat serta berbagai jenis penyakit lainnya pada tanaman hortikultura Hal ini menjadi alternatif yang sangat efektif akan tetapi disamping itu penggunaan bahan-bahan kimia sebagai fungisida menyebabkan kerusakan dan pencemaran lingkungan. Salah satu penanganan untuk mengendalikan penyakit pada tanaman adalah dengan menggunakan pestisida jenis fungisida nabati. Fungisida nabati merupakan jenis pestisida yang berasal dari bahanbahan alam. Ekstrak dari tumbuhan dapat dimanfaatkan sebagai insektisida atau fungisida nabati. Jika dibandingkan dengan fungisida sintetis, penggunakan fungisida nabati lebih aman dan ramah lingkungan (Djojosumanto et al, 2008).

Berdasarkan hal tersebut maka dalam penelitian ini akan dilakukan pengekstrakan kulit buah kakao sebagai fungisida nabati berbahan kandungan fenolik yang digunakan untuk menekan pertumbuhan jamur $F$. oxysporum penyebab penyakit layu fusarium pada tanaman tomat (Solanum lycopersicum).

\section{METODE PENELITIAN}

- Alat

Perangkat alat gelas, spatula, botol sprayer, blender, neraca analitik, hot plate, oven, dan mikropipet.

- Bahan

kulit buah kakao, bibit tomat, tanah, arang sekam padi, kompos, pupuk polybag, aquades, aseton, alkohol $70 \%$, kertas saring, medium PDA, dan aluminium foil

\section{- Prosedur Kerja}

Meliputi pengkajian literatur, persiapan sampel, ekstraksi sampel dan pengujian antijamur secara in vivo

\section{- Preparasi Sampel}

Sampel kulit buah kakao (Theobroma cacao) diperoleh dari Kabupaten Bulukumba, Sulawesi Selatan. Sampel kulit buah kakao yang diambil adalah kakao jenis forastero yang masih segar dan berwarna kuning. Sampel kulit buah kakao diambil dan dikumpulkan sebanyak $20 \mathrm{~kg}$ kemudian kulit buah segar disortasi basah dengan dicuci air mengalir lalu dikering anginkan. Selanjutnya sampel dibawa ke laboratorium penelitian. Sampel kemudian dipotong-potong kecil $1 \times 1 \mathrm{~cm}$ lalu di kering anginkan lagi. Kulit buah kakao yang telah dibersihkan kemudian dikeringkan dengan oven pada suhu $60^{\circ} \mathrm{C}$ hingga menjadi keras dan beratnya konstan waktu yang dibutuhkan selama 3 x 24 jam. Kemudian dihaluskan menggunakan blender untuk mendapatkan simplisia. Kulit buah kako (Theobroma cacao) diekstraksi dengan menggunakan metode maserasi menggunakan pelarut aseton : air (7:3) dengan perbandingan (1:3) untuk sampel kering. Sampel yang telah dihaluskan ditimbang sebanyak 300 gr dan dimasukkan kedalam masing-masing toples dan direndam pelarut sebanyak $1000 \mathrm{ml}$. perendaman dilakukan selama 24 jam pada suhu kamar dan diulangi selama 3 kali. Maserat yang diperoleh disaring dengan menggunakan kertas saring whatman kemudian dipekatkan dengan water bath pada 
suhu $60^{\circ} \mathrm{C}$ hingga diperoleh ekstrak yang kental. Setelah itu dihitung persentase randemen dengan rumus:

$$
\text { Randemen ekstrak }(\%)=\frac{\text { bobot total ekstrak }}{\text { berat bubuk simplisa total }} \times 100
$$

- Persiapan Tanaman Tomat

Persiapan tanaman tomat diawali dengan persiapan benih, dimana benih terlebih dahulu direndam dengan air hangat selama 10 menit, benih yang terapung dibuang. Benih yang baik ditanam dalam polibag kecil yang telah diisi dengan media tanah yang telah disiram, selanjutnya ditutup dengan plastik dan dibiarkan selama 3 hari (saat mulai berkecambah), setelah itu penutupnya dibuka dan dibiarkan selama 15 hari sambil disiram 2 kali sehari. Saat bibit telah memiliki 4 helai daun dipindahkan ke polybag yang berukuran lebih besar yang berisi campuran tanah, kompos dan arang sekam dengan perbandingan 2:1:1 yang sebelumnya telah disemprotkan dengan fingisida sintetis untuk mensterilkan ataupun meminimalisir tumbuhnya jamur di dalam tanah yang bersifat pathogen, kemudian diletakkan di dalam green house.

- persiapan mikroba fusarium sebagai inoculum dan pembuatan formulasi ekstrak

$F$. oxysporum f.sp. lycopersici dibuat dengan menggunakan biakan $F$. oxysporum f.sp. lycopersici yang diambil dari cawan petri, pemanenan spora jamur dilakukan dengan memasukkan aquades steril sebanyak $5 \mathrm{ml}$ untuk setiap cawan petri lalu dikerok dengan halus menggunakan scalpel. Setelah itu semua jamur dikumpulkan dalam dalam tabung cuvet kemudian dilakukan pemisahan natan dan supernatannya menggunakan centrifuge, lalu diambil natannya dan ditambahkan dengan aquadest $20 \mathrm{ml}$, setelah itu dilakukan pengenceran bertingkat sampai 3 kali, dan menghitung jumlah spora menggunakan haemocytometer, selanjutnya dibuat formulasi sebanyak 1 liter dengan kerapatan spora 1x $10^{6}$ konidia/ 1 L Ekstrak kasar kulit buah kakao diformulasikan menjadi fungisida nabati dengan menambahkan aquadest steril. Persentase konsentrasi ekstrak yang dibuat terdiri dari $2 \% ; 5 \% ; 8 \%$ $(\mathrm{g} / \mathrm{v})$. Formulasi selanjutnya digunakan untuk menguji aktivitas antijamur terhadap F. oxysporum secara in vivo (skala green house). Sebagai kontrol positif digunakan fungisida sintetis yaitu benomyl

- Inokulasi fusariumdan Aplikasi Formulasi Ekstrak Buah Kakao

Inokulasi jamur $F$. oxysporum f.sp. lycopersici dilakukan 1 hari setelah tomat dipindahkan ke polybag besar dengan menyemprotkan $20 \mathrm{ml}$ suspensi F. oxysporum f.sp. lycopersici dengan kerapatan spora $1 \times 10^{6}$ konidia $/ 1$ L air pada semua polybag, kecuali polybag pada perlakuan kontrol sehat.

Penelitian dilapangan menggunakan Rancangan Acak Lengkap (RAL) dengan enam perlakuan, yaitu:

1. P0 (tanaman sehat tanpa perlakuan)

2. $\mathrm{P} 1$ (tanaman sakit perlakuan $F$. oxysporum)

3. P2 (perlakuan $2 \%$ ekstrak kulit buah kakao + perlakuan $F$. oxysporum)

4. P3 (perlakuan 5\% ekstrak kulit buah kakao + perlakuan F. oxysporum)

5. P4 (perlakuan $8 \%$ ekstrak kulit buah kakao + perlakuan $F$. oxysporum)

6. P5 (perlakuan benomyl + perlakuan $F$. oxysporum) perlakuan ini sebagai kontrol positif dengan menggunakan fungisida sintetis berupa benlox berbahan kandungan benomyl

Dalam percobaan ini, dibutuhkan 30 tanaman tomat untuk 6 perlakuan dengan 5 ulangan. masing- masing polybag berisi 1 tanaman tomat dan 5 ulangan sehingga dibutuhkan 30 tanaman. 
Aplikasi fungisida benomyl dan ekstrak kulit buah kakao dilakukan setiap 1 minggu sekali selama 4 minggu, yaitu 1 hari setelah tanam, minggu ke-2, 3 dan 4 dengan menyemprotkan $100 \mathrm{ml} /$ tanaman fungisida benomyl dan ekstrak kulit buah kakao ke tanah polybag sekitar batang tanaman tomat.

Variabel yang diamati yaitu, daya hambat fungisida alami dan sintetis, persentase layu pada tanaman tomat, tinggi tanaman, jumlah dan berat buah tomat. Pengambilan data layu daun diamati 1 minggu sekali yakni, minggu pertama sesudah perlakuan, minggu ke-2, 3 dan 4. Untuk data tinggi tanaman diambil data tinggi awal tanaman yaitu tinggi tanaman pada saat perlakuan pertama dan data tinggi tanaman setelah tanaman tomat berbuah, adapun untuk data jumlah dan berat buah diambil setelah buah tomat masak. Data diambil kurang lebihl bulan.

\section{HASIL PENELITIAN}

a. Hasil Ekstraksi Kulit Buah Kakao

Hasil ekstrak yang diperoleh dari proses maserasi 1200-gram sampel yaitu 350-gram ekstrak kulit buah kakao dengan nilai randemen 29,16\%.

b. Tinggi Maksimum Tanaman

Pengukuran tinggi maksimum tanaman tomat dilakukan saat tanaman tomat mulai berbuah. Rata-rata tinggi maksimum dapat dilihat di tabel 1.

Tabel 1. Tinggi Maksimum Tanaman pada minggu ke-4 pengamatan

\begin{tabular}{|l|c|}
\hline \multicolumn{1}{|c|}{ Perlakuan } & $\begin{array}{c}\text { Rata-rataTinggi } \\
\text { maksimum tanaman (\%) }\end{array}$ \\
\hline P0 (kontrol sehat) & $107,00^{\mathrm{b}}$ \\
\hline P1 (kontrol sakit) & $71,00^{\mathrm{a}}$ \\
\hline P2 (ekstrak 2\%) & $70,00^{\mathrm{a}}$ \\
\hline P3 (ekstrak 5\%) & $103,00^{\mathrm{b}}$ \\
\hline P4 (ekstrak 8\%) & $105,40^{\mathrm{b}}$ \\
\hline P5 (kontrol positif) & $96,40^{\mathrm{b}}$ \\
\hline
\end{tabular}

Keterangan: Huruf yang sama menunjukkan hasil yang "berbeda tidak nyata dan huruf yang berbeda menunjukkan hasil yang "berbeda nyata" berdasarkan uji duncan dengan taraf kepercayaan $\alpha 0,05$.

Hasil uji statistik menggunakan ANOVA (Analysis of Variance) yang dilanjutkan dengan uji lanjut Duncan (lampiran 2) menunjukkan bahwa rata-rata tinggi tanaman tertinggi pada perlakuan P0 $(107,00 \%)$ dan terendah pada perlakuan P2 (70,00 \%). P0 berbeda tidak nyata dengan P3, P4 dan P5, tetapi berbeda sangat nyata dengan P1 dan P2. P1 berbeda tidak nyata dengan P2 tetapi berbeda sangat nyata denga P0, P3, P4 dan P5.

- Jumlah Buah 
Penghitungan jumlah buah tomat setiap tanaman dilakukan setelah panen. Adapun hasil yang didapatkan menunjukkan perbedaan dari setiap perlakuan. Ratarata jumlah buah dapat dilihat di tabel 2.

Tabel 2. Rata-rata Jumlah Buah

\begin{tabular}{|c|c|}
\hline Perlakuan & $\begin{array}{c}\text { Rata-rata } \\
\text { Jumlah buah } \\
(\%)\end{array}$ \\
\hline P0 (kontrol sehat) & $9,00^{\mathrm{d}}$ \\
\hline P1 (kontrol sakit) & $1,80^{\mathrm{ab}}$ \\
\hline P2 (ekstrak 2\%) & $1,20^{\mathrm{a}}$ \\
\hline P3 (ekstrak 5\%) & $6,40^{\mathrm{cd}}$ \\
\hline P4 (ekstrak 8\%) & $9,20^{\mathrm{d}}$ \\
\hline P5 (kontrol positif) & $4,60^{\mathrm{bc}}$ \\
\hline
\end{tabular}

Keterangan: Huruf yang sama menunjukkan hasil yang "berbeda tidak nyata dan huruf yang berbeda menunjukkan hasil yang "berbeda nyata" berdasarkan uji duncan dengan taraf kepercayaan $\alpha 0,05$

Hasil uji statistik menggunakan ANOVA (Analysis of Variance) yang dilanjutkan dengan uji lanjut Duncan (lampiran 2) menunjukkan bahwa rata-rata persentase penyakit layu fusarium tertinggi yaitu pada perlakuan P4 $(9,20 \%)$ dan terendah pada perlakuan P2(1,20\%). Pelakuan P0 berbeda tidak nyata dengan P4, tetapi berbeda sangat nyata dengan P1, P2, P3 dan P5. Perlakuan P1 berbeda nyata dengan P2 tetapi berbeda sangat nyata denga P0, P3, P4 dan P5. Perlakuan P3 berbeda nyata dengan P0 dan P4 dan sangat berbeda nyata dengan P1, P2 dan P5.

- Berat Buah

Pengukuran berat buah tomat dilakukan setelah buah tomat dipanen. Hasil analisis menunjukkan rata-rata berat buah yang berbeda dari setiap perlakuan. Ratarata berat buah dapat dilihat di tabel 3 .

Tabel 3. Rata-Rata Berat Buah setelah panen

\begin{tabular}{|c|c|}
\hline Perlakuan & $\begin{array}{c}\text { Rata-rata berat } \\
\text { buah }(\%)\end{array}$ \\
\hline $\begin{array}{c}\text { P0 (kontrol } \\
\text { sehat) }\end{array}$ & $226,00^{\mathrm{c}}$ \\
\hline P1 (kontrol sakit) & $25,80^{\mathrm{a}}$ \\
\hline P2 (ekstrak 2\%) & $11,80^{\mathrm{a}}$ \\
\hline P3 (ekstrak 5\%) & $157,60^{\mathrm{b}}$ \\
\hline P4 (ekstrak 8\%) & $252,00^{\mathrm{c}}$ \\
\hline
\end{tabular}




\begin{tabular}{|c|c|}
\hline $\begin{array}{c}\text { P5 (kontrol } \\
\text { positif) }\end{array}$ & $118,20^{\mathrm{b}}$ \\
\hline
\end{tabular}

Keterangan: Huruf yang sama menunjukkan hasil yang "berbeda tidak nyata dan huruf yang berbeda menunjukkan hasil yang "berbeda nyata" berdasarkan uji duncan dengan taraf kepercayaan $\alpha 0,05$.

Hasil uji statistik menggunakan ANOVA (Analysis of Variance) yang dilanjutkan dengan uji lanjut Duncan (lampiran 2) menunjukkan bahwa rata-rata berat tertinggi pada perlakuan P4 $(252,00 \%)$ dan terendah pada perlakuan P2(11,80\%). Pada perlakuan P0 berbeda tidak nyata dengan P4, tetapi berbeda sangat nyata dengan P1, P2, P3 dan P5. Perlakuan P1 berbeda tidak nyata dengan P2 tetapi berbeda sangat nyata denga P0, P3, P4 dan P5. Perlakuan P3 berbeda tidak nyata dengan P5 tetapi sangat berbeda nyata dengan P0, P1, P2 dan P4.

\section{PEMBAHASAN}

- Hasil Ekstrak Kulit Buah Kakao

Hasil penelitian menunjukkan bahwa randemen ekstrak aseton: air (7:3) kulit buah kakao memiliki nilai persentase sebesar $29,16 \%$. Besar kecilnya nilai randemen dipengaruhi oleh jenis pelarut yang digunakan. Semakin besar nilai randemen menunjukkan bahwa semakin banyak senyawa yang dapat ditarik dari sampel. Ekstrak aseton: air (7:3) kulit buah kakao didapatkan dengan dengan ekstaksi kering, dimana tingkat kehalusan dan penghancuran bahan lebih tinggi dibandingkan dengan cara basah. Harborne (1987) menyatakan bahwa struktur molekul yang makin sederhana menyebabakan porositas atau pori-pori bahan makin besar, sehingga pelarut makin mudah berdifusi ke dalam sel-sel bahan yang diekstrak.

Besar kecilnya nilai randemen menunjukkan keefektifan proses ekstraksi. Keefektifan proses ekstraksi dapat dipengaruhi oleh jenis pelarut yang digunakan, ukuran partikel sampel, lamanya waktu ekstraksi dan metode yang digunakan (Alvian et al., 2016).

- Pengaruh Ekstrak Terhadap Perumbuhan Tanaman Tomat Yang Terserang Layu Fusarium

Hasil analisis menunjukkan bahwa setiap perlakuan memberikan pengaruh yang sama terhadap tinggi maksimum tanaman tomat, jumlah buah dan berat buah. Tinggi rendahnya intensitas penyakit pada tanaman memberikan pengaruh yang sangat besar terhadap tinggi maksimum tanaman tomat, jumlah buah dan berat buah. Tingginya rata-rata tinggi tanaman tomat, jumlah buah dan berat buah pada kontrol sehat karena rendahnya intensitas penyakit akibat tidak adanya permberian jamur fusarium. Pada perlakuan ekstrak $8 \%$ tingginya nilai rata-rata tinggi maksimum, jumlah buah dan berat buah dikarenakan kemampuan ekstrak kakao dalam menghambat jamur fusarium sehingga intensitas penyakit sangat rendah akibatnya pertumbuhan tanaman tetap normal sedangkan jumlah buah dan berat buah yang dihasilkan tetap optimal, sama halnya pada kontrol sehat dengan intensitas penyakit yang sangat rendah. Pertumbuhan tanaman tomat yang baik dikarenakan senyawasenyawa dari ekstrak kulit buah kakao yang mampu menghambat jamur fusarium, semakin tinggi konsentrasi ekstrak maka semakin banyak pula senyawa di dalamnya, sehingga kemampuan menghambat jamur fusarium semakin bagus. 
Rendahnya rata-rata tinggi tanaman, jumlah buah dan berat buah pada kontrol sakit diakibatkan karena tidak adanya pemberian fungisida baik sintetis maupun nabati sehingga pertumbuhan jamur fusarium terjadi secara optimal yang menyebabkan intensitas penyakit yang sangat tinggi pada tanaman, akibatnya pertumbuhan menjadi terhambat, produksi buah yang sedikit dan bobot berat buah yang rendah. Untuk perlakuan ekstrak $2 \%$ menunjukkan rata-rata tinggi maksimum, jumlah dan berat buah yang sangat rendah juga, hal ini dikarenakan perlakuan ekstrak 2\% belum mampu menghambat pertumbuhan jamur fusarium yang menyebabkan intensitas penyakit yang sangat tinggi, sehingga rata-rata tinggi tanaman tomat, jumlah buah dan berat buah yang diperoleh sangat rendah pula.

Persentase penyakit layu fusarium sangat mempengaruhi kondisi tanaman tomat, semakin tinggi persentase penyakit maka semakin rendah rata-rata tinggi tanaman, jumlah buah dan bobot buah. Hal ini dikarenakan terjadinya gangguan pada fisiologis tanaman tomat akibat penyakit layu fusarium. metabolisme tidak berjalan dengan baik akibat air tidak dapat diangkut oleh jaringan xylem kedaun yang menyebabkan laju transpirasi yang tinggi dan proses fotosintesis menjadi terhambat. Begitupun sebaliknya semakin rendah persentase penyakit maka persentase tinggi tanaman, jumlah buah dan bobot buah akan semakin tinggi pula hal ini karena fisiologis tanaman tidak terganggu sehingga metabolisme tetap berjalan dengan baik.

Dalam penelitian ini digunakan fungisida sintetis berupa benlox $50 \mathrm{wp}$. Benlox mengandung bahan aktif berupa benomyl, selama ini benlox digunakan untuk mengatasi penyakit layu fusarium dan penyakit rebah semai pada tanaman cabai dan tomat serta berbagai jenis penyakit lainnya pada tanaman hortikultura.

\section{KESIMPULAN}

Berdasarkan hasil penelitian dapat disimpulkan bahwa ekstrak kulit buah kakao (Theobroma cacao L.) $5 \%$ dan $8 \%$ berpengaruh positif dalam menghambat jamur Fusarium oxysporum penyebab penyakit layu fusarium dan berpengaruh terhadap tinggi tanaman, jumlah daun dan berat buah tomat (Solanum lycopersicum). Rata-rata tinggi tanaman, jumlah daun dan berat buah tertinggi adalah pada perlakuan ekstrak $8 \%$ dan terendah pada perlakuan ekstrak $2 \%$

\section{REFERENSI}

Alvian Nerissa., B. Boy R.S., Tri M. 2016. Uji Efektivitas Antibakteri Ekstrak Etanol Daun Krisan (Chrysanthemum morifolum syn. Dendranthema grandiflora Terhadap Staphylococcus aureus dan Escherichia coli [Skripsi]. Yogyakarta (ID): UniversitaS Atma Jaya Yogyakarta.

Djojosumanto P. 2008. Pestisida dan solusinya. Jakarta: PT agromedia Pustaka Press. FAO Bulettin 38: 49-90.

Harborne, J. B. 1987. Metode Fitokimia; Penuntun Cara Modern Menganalisa Tumbuhan. Bandung: ITB

Harsini dan Susilowati. 2007. Pemanfaatan kulit buah kakao dari limbah perkebunan kakao sebagai bahan baku pulp dengan proses organosol V. Jurnal Ilmiah Teknik lingkungan. Vol.2(2): 80-89 
Pengaruh Ekstrak Kulit Buah Kakao (Theobroma cacao) Dalam Menghambat Penyakit Layu Fusarium Terhadap Pertumbuhan Tanaman Tomat

Rachmawaty, A. Mu'nisa., Hasri., Halifah P., Hartati., Zulkifli M. 2018. Active Compounds Extraction of Cocoa Pod Husk (Thebroma cacao l.) and Potential as Fungicides. Journal of Physics Vol 2(2): 1-6

Safitri J. M. dan Aris M. 2007. Pemanfaatan Ekstrak Daun Nimba (Azadirachta indica A. Juss) Untuk Pengendalian Penyakit Layu Fusarium Pada Tanaman Tomat (Lycopersicum esculentum Mill.). Jurnal Biosfera 24 (2) : 71-75. 